University of Nebraska - Lincoln

DigitalCommons@University of Nebraska - Lincoln

$4-4-2008$

\title{
No-Till Corn after Bromegrass: Effect on Soil Carbon and Soil Aggregates
}

\author{
Ronald F. Follett \\ Colorado State University - Fort Collins, ronald.follett@ars.usda.gov \\ Gary E. Varvel \\ University of Nebraska-Lincoln, gevarvel@windstream.net \\ John M. Kimble \\ Kenneth P. Vogel \\ University of Nebraska-Lincoln, kvogel1@unl.edu
}

Follow this and additional works at: https://digitalcommons.unl.edu/usdaarsfacpub

Part of the Agricultural Science Commons

Follett, Ronald F.; Varvel, Gary E.; Kimble, John M.; and Vogel, Kenneth P., "No-Till Corn after Bromegrass: Effect on Soil Carbon and Soil Aggregates" (2008). Publications from USDA-ARS / UNL Faculty. 312. https://digitalcommons.unl.edu/usdaarsfacpub/312

This Article is brought to you for free and open access by the U.S. Department of Agriculture: Agricultural Research Service, Lincoln, Nebraska at DigitalCommons@University of Nebraska - Lincoln. It has been accepted for inclusion in Publications from USDA-ARS / UNL Faculty by an authorized administrator of DigitalCommons@University of Nebraska - Lincoln. 


\title{
No-Till Corn after Bromegrass: Effect on Soil Carbon and Soil Aggregates
}

\author{
Ronald F. Follett,* Gary E. Varvel, John M. Kimble, and Kenneth P. Vogel
}

\begin{abstract}
Grasslands in the Conservation Reserve Program (CRP) in the USA may be converted to grain crops for bioenergy. The effect of no-till conversion of a smooth bromegrass (Bromus inermis Leyss) grassland to no-till corn (Zea mays L.) production on soil organic carbon (SOC) in the western Corn Belt was monitored for over $6 \mathrm{yr}$. A different ${ }^{13} \mathrm{C} /{ }^{12} \mathrm{C}$ isotope signature is imparted to SOC by C4 plants including corn versus $\mathrm{C} 3$ plants such as bromegrass. Changes in $\mathrm{C}$ isotope ratios in SOC in three soil depths (0- to 5-, 5-10, and 10-30 cm) by particle size was also monitored during $\sim 6.5 \mathrm{yr}$ of no-till corn production at two different $\mathrm{N}$ levels $\left(60\right.$ and $\left.120 \mathrm{~kg} \mathrm{ha}^{-1}\right)$. Soil was collected eight times during the study from the 0 - to 5-and 5-to 10 -cm depths, and at four of these times from the 10 - to $30-\mathrm{cm}$ depth from each of the $\mathrm{N}$ rate replicates. Because fertilizer $\mathrm{N}$ had no significant effect over years on any of the aboveground biomass production variables, the data from both $\mathrm{N}$ treatments was combined for regression analysis to determine the effects of years of no-till corn production on SOC variables. Total SOC did not change significantly at any depth during the study, but there was a significant change in the source of the SOC. Total C4-C increased over this time, while C3-C decreased in the 0-to 5- and 5- to 10-cm depth, while neither changed in the 10-to 30-cm depth. In the 0-to 5-and 5- to 10-cm depths, largest loss of C3-C was from 2-mm aggregates, while largest increases in $\mathrm{C} 4-\mathrm{C}$ were in the 1-, 0.5-, 0.25-, and $0.125-\mathrm{mm}$ aggregates. If CRP grasslands are converted to grain crop production, the data from this study strongly support the use of no-till farming practices as a method of conserving the SOC that was sequestered during the time period that the land was in the CRP.
\end{abstract}

$\mathrm{I}^{\mathrm{s}}$ NCREASING ENERGY DEMANDS, declining petroleum reserves, and political instability in oil exporting countries of the world are resulting in increased calls for domestically produced fuels. The current emphasis is to use corn grain for ethanol production. Cassman et al. (2006) estimated that by 2010 to 2011, a capacity of 10 billion gallons of ethanol may exist from corn grain alone. However, there is increasing interest in converting lignocellulosic materials (such as corn stover) into ethanol (Perlack et al., 2005; Graham et al., 2007). Importantly, increased corn production should not be at the expense of soil sustainability (Robertson et al., 2008), including indicators of soil quality such as SOC.

Coupled with the above environmental concerns is the possibility that, if additional lands are converted to corn production, they may include fragile lands such as those currently enrolled in the CRP. The CRP is a U.S. federal program which highlights the need to protect the soil and environmental quality (Cassman 1999; Tilman et al., 2002). If many of the thousands

R.F. Follett, USDA/ARS, Soil-Plant-Nutrient Res. Unit., NRRC, Bldg D, Ste. 100, 2150 Centre Ave., Fort Collins, CO 80526; G.E. Varvel, USDA/ ARS, Agroecosystem Management Research Unit, 120 Keim Hall, and K.P. Vogel, USDA/ARS, Grain, Forage and Bioenergy Research Unit, 314 Biochemistry Hall, Univ. of Nebraska, Lincoln, NE 68583; J.M. Kimble, (NRCS retired), 151 East Hill Church Road, Addison, NY 14801. Received 4 Apr. 2008. ${ }^{*}$ Corresponding author (ronald.follett@ars.usda.gov).

Published in Agron. J. 101:261-268 (2009).

doi:10.2134/agronj2008.0107

Copyright $\odot 2009$ by the American Society of Agronomy, 677 South Segoe Road, Madison, WI 53711. All rights reserved. No part of this periodical may be reproduced or transmitted in any form or by any means, electronic or mechanical, including photocopying, recording, or any information storage and retrieval system, without permission in writing from the publisher of hectares of CRP land that are presently under permanent grass cover (Farm Service Agency, 2007) are converted to corn grain production, such practices as no-till may help lessen the loss of SOC from these lands while maintaining soil structure and resistance to soil erosion. Such maintenance is highly important because of the likelihood that the resulting loss of SOC and soil structure would greatly increase greenhouse gas emission and soil erosion losses (Lal et al., 2007). Should instead, CRP land be converted to production of lignocellulosic materials with large amounts of corn stover removed from the land for ethanol production, then the intent of the CRP to protect the soil might be jeopardized. This danger of environmental degradation increases the importance of having not only suitable information about the amount of crop residue to return to the soil to prevent SOC loss, but also about other potentially viable biofuel crops (i.e., perennial grasses) as a source of lignocellulosic material in lieu of corn stover (Robertson et al., 2008).

Johnson et al. (2006) reported estimates of aboveground vegetative $\mathrm{C}$ to maintain SOC for "minimal amounts of annual source C inputs" (MSC). From their review they found that $1800 \pm 400 \mathrm{~kg}$ of aboveground MSC ha- $\mathrm{yr}^{-1}(n=5)$ was needed in no-tillage and chisel-plow tillage systems. However, for the no-till continuous-corn studies reported (Allmaras et al., 2004; Clapp et al., 2000; Kucharik et al., 2001) by Johnson et al. (2006), the average needed was $2100 \pm 100 \mathrm{~kg}$ of MSC $\mathrm{ha}^{-1} \mathrm{yr}^{-1}(n=3)$. Of considerable concern in relation to the conversion of CRP land from permanent grass cover is the use

Abbreviations: C3-C, carbon from cool season (C3) plants; C4-C, carbon from warm season (C4) plants; CRP, Conservation Reserve Program; MSC, minimal amounts of annual source C inputs; PDSI, Palmer Drought Stress Index; SOC, soil organic carbon. 
of an inversion tillage (plowing, etc.) production system that would result in it being harder to maintain both SOC and soil structure and which would also likely increase the potential for water and/or wind erosion. Again, referring to the literature survey reported by Johnson et al. (2006), an average of $3180 \pm$ $940 \mathrm{~kg}$ of MSC ha-1 $\mathrm{yr}^{-1}(n=6)$ was needed for corn production under moldboard-plowed conditions.

In addition to soil $\mathrm{C}$, soil aggregates are of critical importance to soil productivity and structure. A soil aggregate is a group of primary particles that cohere to each other more strongly than to surrounding soil particles (Kemper and Rosenau, 1986). Aggregate stability and its role in soil structure is a function of how well the cohesive forces between particles withstand an applied disruptive force. Among the forces involved in soil aggregation are surface tension of air and water interfaces; that of soluble compounds such as silica, carbonates, and organic molecules that become concentrated at the junctions of adjacent particles as the soil dries; and structural form including secondary structures (aggregates or peds) that are distinguished from adjacent structures on the basis of fracture zones of different strength. Fragmentation of the soil matrix (e.g., by tillage) occurs via fracture zones and soil structural stability is the ability of soil to retain its arrangement of solid and void spaces when exposed to different stresses (Kay, 1997). Form, stability, and resiliency of soil structure are strongly influenced by soil texture, clay mineralogy, exchangeable ions, SOC content, and by the nature and quantities of organic cementing materials present. Biological processes that influence soil structure, aggregate stability, and SOC include growth of plant roots (density and size), activity of soil flora (bacteria and fungi), and soil fauna (e.g., earthworms, amoebae).

The properties and dynamics of SOC and organic materials that are important to soil structure include their ability to strengthen failure zones between primary soil particles, persistence, and capacity to absorb, store, or transmit water. Presence of decomposable plant material and readily mineralizable $\mathrm{C}$ aides the growth of microorganisms and their predators. Work by Foster (1988) showed that microorganisms and their extracellular materials can become intimately associated with mineral material. Part of the microbial biomass (both bacterial and fungal) may grow into or be squeezed into pores along with extracellular material when adjacent to plant residues. Microbial mucilage may penetrate the soil matrix as much as $50 \mu \mathrm{m}$ from beyond the surface of plant residues (Foster, 1988). Polysaccharides are strongly adsorbed on mineral surfaces and are particularly effective in strengthening failure zones, which accounts for their high correlation with aggregate stability and readily extractable carbohydrates as reported by Chaney and Swift (1984); Haynes and Swift (1990); and Angers et al. (1993a, 1993b). Since, over a sufficient period of time, the $\mathrm{C}$ within the above described polysaccharides and microbial breakdown products are plant derived, then the stable $\mathrm{C}$ isotope signature that becomes imparted to SOC and soil aggregates reflects that of the growing crop. Changes in the relative abundance and activity of bacteria versus fungus are considered to affect $\mathrm{C}$ cycling and storage, as influenced by the differential physiologies and interactions of these two microbial groups (Simpson et al., 2004; Six et al., 2006). Simpson et al. (2004) extracted amino sugars from various wet aggregate fractions and determined that fungal derived sugar- $\mathrm{C}$ comprised $63 \%$ and bacterial derived sugar- $\mathrm{C}$ comprised $37 \%$ of the total amino sugar-C pools under both no-till and conventionally tilled fields. However, the no-till soil contained $21 \%$ more amino sugar-C than did the conventional till soil. Their results indicated that microbial-derived C is stabilized in no-till soils, due primarily to a greater fungal-mediated improvement of soil structural stability and concurrent deposition of fungal derived $\mathrm{C}$ into the microaggregates ( 0.053 to $0.25 \mathrm{~mm}$ ) contained in macroaggregates $(<2 \mathrm{~mm})$. Aggregate stability has also been associated with the presence of glomalin, a glycoprotein produced by the hyphae of arbuscular mycorrhizal fungi (Wright and Upadhyaya, 1998; Liebig et al., 2006). Six et al. (2006) found that protection of microbial biomass in soils is related to their interaction with reactive surface properties of the clay. Under no-till, higher fungal biomass is reported to correlate with quantitative improvements in soil organic matter (Six et al., 2006).

The primary information contained in $\delta^{13} \mathrm{C}$ of soil organic matter (or plants and plant material) is related to the photosynthetic pathways of local plants. The dominant photosynthetic pathway of C3 (or cool-season plants) is Calvin-Benson, whereby the enzyme RuBP carboxylase is used to fix carbon. This pathway fractionates the isotopic composition of the plant and $\mathrm{CO}_{2}$ in the air (currently about $-8 \%$ o [Keeling et al., 2001]) to about $-18 \%$. Thus, a typical $\delta^{13} \mathrm{C}$ of C3 (cool season) plants is about -26 to $-27 \%$ (Deines, 1980; Follett et al., 2004). Warm-season C4 plants have the added Hatch-Slack enzymatic pathway that is dominated by PEP-carboxylase to produce a carbon isotope fractionation between the air and the plant of about $-4 \%$. Consequently, the average $\delta^{13} \mathrm{C}$ of C 4 plants is about -11 to $-13 \%$ (Clay et al., 2006; Deines, 1980; Follett et al., 2004). The above difference in $\delta^{13} \mathrm{C}$ signatures imparted on SOC allows use of a C3 C4 plant switch technique to identify the origin of $\mathrm{C}$ in SOC and whether it is from cool-season or warm-season plants. Several studies demonstrate the potential use of $\delta^{13} \mathrm{C}$ isotope technique to trace long-term residue management effects on relic and recent in situ SOC turnover (Clapp et al., 2000; Clay et al., 2006; Follett et al., 1997; Allmaras et al., 2004; Wilts et al., 2004). Because $\delta^{13} \mathrm{C}$ values persist during decomposition and SOC formation, the turnover rate of the SOC can be determined by the rate at which the $\delta^{13} \mathrm{C}$ of the SOC changes to approach that of the new plant community (Balesdent and Marriotti, 1996; Balesdent et al., 1988; Boutton 1991, 1996).

The purpose of this study was to determine the dynamics of the gain or loss of total SOC when cool-season grasslands similar to those in the CRP are converted to no-till corn production in the midwestern United States. A field near Mead, NE, that had been in smooth bromegrass for more than 13 yr was used to study the amounts and rates of replacement of $\mathrm{C}_{3}$-derived SOC from bromegrass by $\mathrm{C}_{4}$-derived carbon from corn in soil aggregates with depth during $\sim 6.5 \mathrm{yr}$ and to estimate the amount of corn residue required to maintain the SOC. Smooth bromegrass, or bromegrass, is the most widely used grass in the Midwest for pastures and conservation plantings. 


\section{METHODS AND MATERIALS}

This long-term field study is located on the University of Nebraska Agricultural Research and Development Center, near Mead, NE, USA (41 $\left.{ }^{\circ}{ }^{\prime} 3.6^{\prime \prime} \mathrm{N}, 96^{\circ} 24^{\prime} 3.6^{\prime \prime} \mathrm{W}\right)$ on a Filbert silt loam (fine, smectitic, mesic Vertic Argialboll). In this region, tall and mid-prairie grasses with a mixture of $\mathrm{C} 3-\mathrm{C} 4$ species were the dominant native prairie species on Filbert soil. Corn, soybean [Glycine max (Merr.)], sorghum [Sorghum bicolor (L.) Moench], and small grains are produced on this soil when under cultivation. The experimental site, previously in corn was placed into continuous smooth bromegrass (a $\mathrm{C}_{3}$ plant) in 1986. The bromegrass sod was killed using glyphosate $\left(2.2 \mathrm{~kg}\right.$ a.i. $\mathrm{ha}^{-1}$ ) applied in November 1998 . The corn ( $\mathrm{a} \mathrm{C}_{4}$ plant) was no-till seeded into the herbicide-killed bromegrass sod in spring of 1999 . The study was rainfed. The original experimental design included three main treatments $(r=3)$, which were: (i) bromegrass converted to no-till corn (corn treatment), (ii) bromegrass converted no-till to perennial warm-season grasses, and (iii) original plots of smooth bromegrass. Each of the main plots had two subplots which were $\mathrm{N}$ fertilizer rates. Because of drought conditions, uniform stands of warm-season grasses were not obtained during the first $3 \mathrm{yr}$ of the study. Because of the critical problem of the fate of soil C when CRP land is converted to grain crops, the study was modified to focus on the fate of SOC when bromegrass is converted to no-till corn production. The three main corn plots were converted into replicates. The $\mathrm{N}$ rate subplot treatments became main treatment effects in a randomized complete block experiment design with three replicates. The replicates were 32-m-long by 5.2-m-wide strips of corn, planted no-till between 3 -m-wide strips of undisturbed bromegrass sod. Treatments were $\mathrm{N}$ fertilizer rate (60 and $120 \mathrm{~kg} \mathrm{~N} \mathrm{ha}^{-1} \mathrm{yr}^{-1}$ ) as $\mathrm{NH}_{4} \mathrm{NO}_{3}$ broadcast on the plots at the start of each growing season. Corn replicates were split lengthwise to form the treatment plots. The $\mathrm{N}$ rate treatments, which represent the low and high ends of the recommended range for no-till rainfed corn in the region, were used to determine the effect of $\mathrm{N}$ fertilization on SOC when cool-season grasslands are converted to corn production. Herbicides were used for weed control as needed. No-till corn production and associated soil sampling was conducted for $6 \mathrm{yr}$ on the plots. Time after conversion thus is a primary experimental variable.

Aboveground dry matter samples (one row, $4.4 \mathrm{~m}$ long) were collected soon after physiological maturity. Ears were removed and stalks then cut at ground level, chopped, and weighed. A representative subsample was collected, dried, and weighed for gravimetric moisture determination to calculate stover dry matter production. Ears were dried and weighed, added to the calculated stover weight, and total dry matter production was determined (Table 1). Plot yields were adjusted to a dry-weight basis.

Soil samples were obtained periodically during 6.42 yr (77 mo) with sampling at shorter time intervals during the earlier years. Dates of sampling and number of months the study was conducted were in May 1999 (0 yr), September 1999 (0.33 yr), June 2000 (1.08 yr), October 2000 (1.42 yr), September 2001 (2.33 yr), November 2002 (3.5 yr), September 2003 (4.33 yr), and October 2005 (6.42 yr). To determine the location for soil sample collection, an area of 2.9 by $2.1 \mathrm{~m}$ was established in the center of each plot. Within this area, 10 randomized subsampling areas measuring 0.6 by $0.3 \mathrm{~m}$ were identified and numbered from 1 to 10 . Eight of these subsampling areas were randomly sampled during the $6.42 \mathrm{yr}$ of this experiment, with one sampled at each of the above-listed dates. Sample collection within the subsampling area was done by first removing the plant material from the soil surface and then, using a flat-bladed shovel, undercutting and removing the soil from the 0 - to $5-\mathrm{cm}, 5$ - to $10-\mathrm{cm}$, and at four of the eight times also removing soil samples from the 10- to 30 -cm depths. Soil bulk densities (33 kPa of moisture tension) were determined on clods from each soil layer and coated with Saran F-310 for transport and measurement of soil bulk density (Burt, 2004).

Following collection, the moist soil was passed through an 8-mm sieve before air drying and storing for later separation into the reported size fractions. Four laboratory replications, each $50 \mathrm{~g}$ of air-dried soil, from each field plot were rewetted on ceramic wetting plates and placed on top of o-rings sitting in pans. After transferring the soil onto the wetting plates, distilled water was added to each pan until it reached halfway up the sides of the wetting plates. Once completely wetted, the soil was carefully and completely transferred to the top sieve of a set of nested sieves that assembled into an aggregate analysis apparatus similar to that first described by Yoder (1936). Following assembly, the sieves were placed into a Plexiglas column filled to a predetermined level with distilled water. The nested sieve sizes were $2,1,0.5$, and $0.25 \mathrm{~mm}$. Once all sieves were in place on the Yoder apparatus, they were agitated for $15 \mathrm{~min}$ at a speed that was slow enough to fully separate the aggregates without breaking them (a 2.6-cm length stroke repeated 30 times $\mathrm{min}^{-1}$ ) (adapted from Yoder, 1936). After separation, the aggregate fractions were rinsed from their respective sieves into separate sample cups. Detritus which floated to the surface in the sample cups was skimmed off of the surface and transferred

Table I. Stover, stover carbon, grain, and total yields (dry weights) for no-till corn near Mead, NE, (1999-2005).

\begin{tabular}{|c|c|c|c|c|c|}
\hline Year & $\begin{array}{c}\text { Fertilizer } \\
\mathbf{N} \text { rate }\end{array}$ & $\begin{array}{l}\text { Stover } \\
\text { yield }\end{array}$ & $\begin{array}{l}\text { Stover } \\
\text { carbon }\end{array}$ & $\begin{array}{l}\text { Grain } \\
\text { yield }\end{array}$ & $\begin{array}{c}\text { Total dry } \\
\text { matter }\end{array}$ \\
\hline & & & $-\mathrm{kg} \mathrm{ha}^{-1}$ & & \\
\hline \multirow[t]{2}{*}{1999} & 60 & $|2,70|$ & 5,334 & 8,466 & 21,167 \\
\hline & 120 & $|I, 66|$ & 4,898 & 10,439 & 22,100 \\
\hline \multirow[t]{2}{*}{2000} & 60 & 13,238 & 5,560 & 9,517 & 22,755 \\
\hline & 120 & II,367 & 4,774 & 8,051 & 19,418 \\
\hline \multirow[t]{2}{*}{2001} & 60 & 6,466 & 2,716 & 4,223 & 10,689 \\
\hline & 120 & 6,582 & 2,764 & 3,633 & $|0,2| 4$ \\
\hline \multirow[t]{2}{*}{2002} & 60 & 5,179 & 2,175 & 2,684 & 7,863 \\
\hline & 120 & 5,040 & 2,117 & I,927 & 6,967 \\
\hline \multirow[t]{2}{*}{2003} & 60 & ND† & ND & ND & ND \\
\hline & 120 & ND & ND & ND & ND \\
\hline \multirow[t]{2}{*}{2004} & 60 & 7,982 & 3,352 & 9,724 & 17,706 \\
\hline & 120 & 9,620 & 4,040 & II,382 & 21,002 \\
\hline \multirow[t]{2}{*}{2005} & 60 & 7,066 & 2,968 & 6,275 & $|3,34|$ \\
\hline & 120 & 7,765 & 3,261 & 5,638 & 13,403 \\
\hline Total, & 60 & 52,632 & 22,105 & 40,889 & 93,521 \\
\hline 1999-2005 & 120 & 52,035 & 21,854 & 41,070 & 93,104 \\
\hline \multicolumn{2}{|c|}{ Source of variation } & \multicolumn{4}{|c|}{ ANOVA $(P>F)$} \\
\hline \multicolumn{2}{|c|}{ Year } & $<0.001$ & $<0.001$ & $<0.001$ & $<0.001$ \\
\hline \multicolumn{2}{|c|}{ N-rate } & 0.777 & 0.777 & 0.922 & 0.880 \\
\hline \multicolumn{2}{|c|}{ Year $\times \mathrm{N}$-rate } & 0.087 & 0.087 & 0.009 & 0.007 \\
\hline
\end{tabular}

$\dagger N D$, no data due to drought and lack of sufficient dry matter growth. 
into a separate container. To separate the $0.125-\mathrm{mm}$ fraction, material passing through the $0.25-\mathrm{mm}$ sieve was washed gently through an additional $0.125-\mathrm{mm}$ sieve, with the final fraction that passed all of the sieves being the $<0.125-\mathrm{mm}$ size. Aggregate fraction samples were dried at $55^{\circ} \mathrm{C}$, weighed, subsampled, and ground for subsequent analyses. All samples were analyzed for total SOC and ${ }^{13} \mathrm{C} /{ }^{12} \mathrm{C}$ isotope ratio using a Europa Scientific 20-20 Stable Isotope Analyzer (isotope ratio mass spectrometer) continuous flow interfaced with Europa Scientific ANCA-NT system (automated nitrogen carbon analyzer) Solid/Liquid Preparation Module (Dumas combustion sample preparation system) (Sercon Ltd., Europa Scientific, Crewe Cheshire, UK). ${ }^{1}$

Equation [1] expresses ${ }^{13} \mathrm{C} /{ }^{12} \mathrm{C}$ ratio as $\delta^{13} \mathrm{C}$. By convention, $\delta^{13} \mathrm{C}$ values are expressed relative to a calcium carbonate standard known as PDB from the Cretaceous Pee Dee formation in South Carolina (Boutton, 1991). Sign of $\delta^{13} \mathrm{C}$ indicates whether a sample has a higher or lower ${ }^{13} \mathrm{C} /{ }^{12} \mathrm{C}$ isotope ratio than does PDB.

$$
\delta^{13} \mathrm{C}(\% 0)=\frac{\left({ }^{13} \mathrm{C} /{ }^{12} \mathrm{C}\right) \text { sample }-\left({ }^{13} \mathrm{C} /{ }^{12} \mathrm{C}\right) \text { reference }}{\left({ }^{13} \mathrm{C} /{ }^{12} \mathrm{C}\right) \text { reference }} \times 1000
$$

Besides measurements of total $\mathrm{C}$ and $\delta^{13} \mathrm{C}$, fraction and weight of $\mathrm{C}$ originating from $\mathrm{C} 3$ plants (from bromegrass, previously grown in these plots) and C4 plants (no-till corn planted in 1999) were calculated based on the measured $\delta^{13} \mathrm{C}$ values of plant material (Follett et al., 2004) and by the use of the following equations:

$$
\begin{aligned}
& \text { C3 plant C }(\%)=\frac{\left(\delta^{13} \mathrm{C} \text { sample }-\delta^{13} \mathrm{C} \text { of } \mathrm{C} 4 \text { crop }\right) \times 100}{\left(\delta^{13} \mathrm{C} \text { of } \mathrm{C} 3 \text { crop }-\delta^{13} \mathrm{C} \text { of } \mathrm{C} 4 \text { crop }\right)} \\
& \text { C4 plant } \mathrm{C}(\%)=\frac{\left(\delta^{13} \mathrm{C} \text { of } \mathrm{C} 3 \text { crop }-\delta^{13} \mathrm{C} \text { sample }\right) \times 100}{\left(\delta^{13} \mathrm{C} \text { of } \mathrm{C} 3 \text { crop }-\delta^{13} \mathrm{C} \text { of } \mathrm{C} 4 \text { crop }\right)}
\end{aligned}
$$

Analysis of variance was used to determine the effect of fertilizer $\mathrm{N}$ on stover and grain yield, stover $\mathrm{C}$, and total dry matter production. Because fertilizer $\mathrm{N}$ had no significant effect over years on any of the aboveground biomass production variables, the data from both $\mathrm{N}$ treatments was combined for regression analysis to determine the effects of years of no-till corn production on SOC variables. Linear regression was conducted by soil depth layers to determine (i) change in total SOC, (ii) the rates of soil carbon loss from the pool of C3-C that was present at the beginning of the study under the bromegrass sod before the no-till corn was planted, (iii) the rates of sequestration of carbon being added to the existing pool of C4-C as a result of the corn grown on these plots for $6.42 \mathrm{yr}$.

Regression analysis was used to determine changes in C3-C and $\mathrm{C} 4-\mathrm{C}$ within particle size groups within the specific soil layers. Rows of data in Tables 2, 3, and 4 shown in bold lettering highlight significant regression effects. Italicized rows of data indicate that the values observed reached borderline significance. The results are considered nonconclusive for rows that are neither bold nor italicized.

\footnotetext{
${ }^{1}$ Trade and company names are included for the benefit of the reader and do not imply endorsement or preferential treatment of the product by the authors or the USDA.
}

Table 2. Linear regression of SOC type (C3 or C4) by soil aggregate particle size for the 0 - to $5-\mathrm{cm}$ soil depth $(n=48)$ on years of no-till, rainfed corn production near Mead, NE,

\begin{tabular}{|c|c|c|c|c|}
\hline \multirow{2}{*}{$\begin{array}{c}\text { Soil } \\
\text { aggregate size }\end{array}$} & \multicolumn{4}{|c|}{ Linear regression statistics $\dagger$} \\
\hline & $a$ & b & $r^{2}$ & $P$ \\
\hline $\mathrm{mm}$ & $\mathrm{Kg} \mathrm{ha}^{-1}$ & $\mathrm{Kg} \mathrm{ha}^{-1} \mathrm{yr}^{-1}$ & & \\
\hline \multicolumn{5}{|l|}{ C4 } \\
\hline 2 & 3,670 & -29 & 0.005 & 0.638 \\
\hline$I \ddagger$ & I,045 & 210 & $0.3 \mathrm{I} I$ & $<0.001$ \\
\hline 0.5 & 567 & 202 & 0.536 & $<0.001$ \\
\hline 0.25 & 253 & 117 & 0.548 & $<0.001$ \\
\hline 0.125 & 166 & 98 & 0.555 & $<0.001$ \\
\hline$<0.125$ & 206 & 78 & 0.528 & $<0.001$ \\
\hline \multicolumn{5}{|l|}{$\mathrm{C} 3$} \\
\hline 2 & 7,936 & -793 & 0.504 & $<0.001$ \\
\hline I & 2,436 & 5 & 0.000 & 0.929 \\
\hline 0.5 & 2,003 & $-1 \mid$ & 0.001 & 0.799 \\
\hline 0.25 & 1,016 & 16 & 0.012 & 0.463 \\
\hline 0.125 & 816 & 30 & 0.028 & 0.256 \\
\hline$<0.125$ & 534 & 20 & 0.048 & 0.136 \\
\hline
\end{tabular}
during the period 1999 to 2005 on land formerly in smooth bromegrass.

Table 3. Linear regression of SOC type (C3 or C4) by soil aggregate particle size for the 5 - to $10-\mathrm{cm}$ soil depth $(n=48)$ on years of no-till, rainfed corn production near Mead, NE,

\begin{tabular}{|c|c|c|c|c|}
\hline \multirow{2}{*}{$\begin{array}{l}\text { Soil } \\
\text { aggregate size }\end{array}$} & \multicolumn{4}{|c|}{ Linear regression statistics $\dagger$} \\
\hline & $a$ & b & $r^{2}$ & $\boldsymbol{P}$ \\
\hline $\mathrm{mm}$ & $\mathrm{Kg} \mathrm{ha}^{-1}$ & $\mathrm{Kg} \mathrm{ha}^{-1} \mathrm{yr}^{-1}$ & & \\
\hline \multicolumn{5}{|l|}{ C4 } \\
\hline $2 \ddagger$ & 4,805 & -146 & 0.121 & 0.015 \\
\hline $1 \S$ & 1,212 & 242 & 0.570 & $<0.001$ \\
\hline 0.5 & 868 & 90 & 0.337 & $<0.001$ \\
\hline 0.25 & 319 & 37 & 0.356 & $<0.001$ \\
\hline 0.125 & 216 & II & 0.041 & 0.168 \\
\hline$<0.125$ & 412 & -23 & 0.058 & 0.098 \\
\hline \multicolumn{5}{|l|}{ C3 } \\
\hline 2 & 4,520 & -280 & 0.224 & $<0.001$ \\
\hline I & $\mathrm{I}, \mathrm{I} 44$ & 106 & 0.360 & $<0.001$ \\
\hline 0.5 & 875 & 10 & 0.009 & 0.512 \\
\hline 0.25 & 391 & 2 & 0.002 & 0.782 \\
\hline 0.125 & 333 & -14 & 0.057 & 0.101 \\
\hline$<0.125$ & 430 & -31 & 0.098 & 0.030 \\
\hline \multicolumn{5}{|c|}{$\dagger a$ and $b$ represent the intercept and regression coefficient, respectively. } \\
\hline \multicolumn{5}{|c|}{$\begin{array}{l}\ddagger \text { Italicized rows of data indicate that the values observed reached borderline } \\
\text { significance. }\end{array}$} \\
\hline \multicolumn{5}{|c|}{ § Bolded rows highlight significant regression effects. } \\
\hline
\end{tabular}
during the period 1999 to 2005 on land formerly in smooth bromegrass.

All statistical analyses of data from this study were performed using SigmaStat 3.0 (SPSS Inc., Chicago, IL).

\section{RESULTS}

\section{Plant Dry Matter Yields}

The precipitation at the field site varied significantly over the 6 yr of the study in which there were some significant periods of drought as indicated by the Palmer Drought Stress Index (PDSI) (Fig. 1). Negative PDSI values indicate degree of drought severity. The PDSI for east central NE as shown in Fig. 1B shows the severity of the 2002-2003 drought as well as a period of preceding drought that had occurred in 2000. At the Mead weather station, the 2002 May, June, and July precipitation was $161 \mathrm{~mm}$ ( $58 \%$ of normal), with an additional $135 \mathrm{~mm}$ falling between November 2002 into May 2003; the 
subsequent precipitation and timing did not result in a harvestable crop in 2003 (Fig. 1A).

As would be expected, grain, stover, and total biomass yields were strongly influenced by precipitation (Table 1; Fig. 1). There were no significant effects of $\mathrm{N}$ fertilizer rates for stover, grain, total biomass, or stover $\mathrm{C}$ yields during the study (Table 1). This was likely due to drought effects and the resulting carryover of soil $\mathrm{N}$ into the subsequent growing season. There were significant year effects for all yield traits as a result of differences in growing season precipitation. Year $\times$ $\mathrm{N}$ interaction effects were not significant at $P<0.05$ for stover yields or for stover carbon but were significant for grain and total biomass (grain + stover) yield. This was likely due to the effects of available moisture on grain fill and yield. Stover yields ranged from 0 to $13,240 \mathrm{~kg} \mathrm{ha}^{-1}$, average of $7,480 \mathrm{~kg} \mathrm{ha}^{-1}$ (for 1999 to 2004). Amount of stover-C4 plant carbon available (assuming stover to contain $\sim 42 \% \mathrm{C}$ ) (Follett, unpublished data, 2006) for return to the soil annually ranged from 0 to 5,560 (average of 3,140) $\mathrm{kg} \mathrm{C} \mathrm{ha}^{-1}$ (for 1999 to 2004), during this field study (Table 1).

\section{Soil Organic Carbon}

Total Soil Organic Carbon, C3-Carbon, and C4-Carbon

The total SOC, C3-C, and C4-C present in each of the soil depths at the beginning of this study are represented with the amounts shown in May 1999 (0.0 yr), in Fig. 2, 3, and 4, and reflect photosynthetic $\mathrm{C}$ sequestered in the soil from plants and crops that had grown on this site before and including the
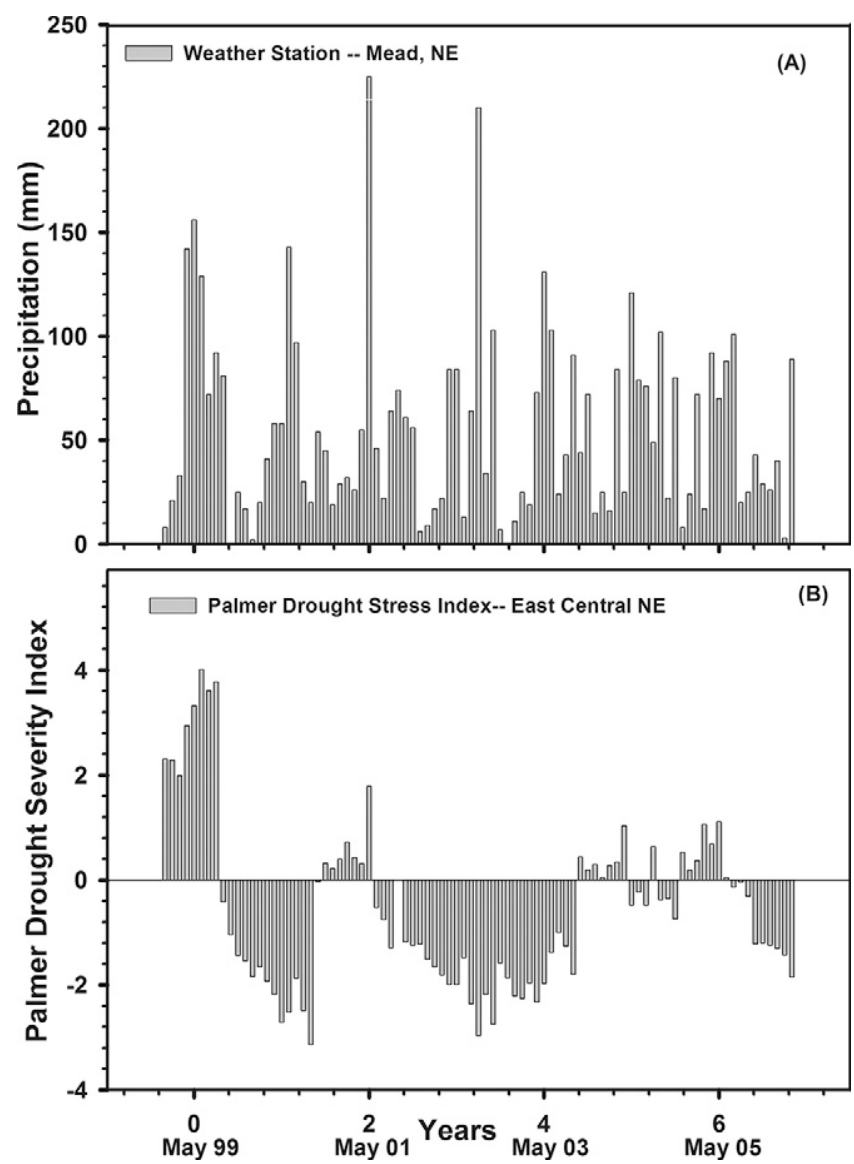

Fig. I. Graph of the (A) Precipitation at Mead, NE, and (B) the Palmer Drought Severity Index (PDSI) for east central NE. (http://www7.ncdc.noaa.gov/CDO/CDODivisionalSelect.jsp\#)
Table 4. Linear regression of SOC type (C3 or $\mathrm{C4}$ ) by soil aggregate particle size for the 10 - to $30-\mathrm{cm}$ soil depth $(n=48)$ on years of no-till, rainfed corn production near Mead, NE, during the period 1999 to 2005 on land formerly in smooth bromegrass.

\begin{tabular}{|c|c|c|c|c|}
\hline \multirow{2}{*}{$\begin{array}{c}\text { Soil } \\
\text { aggregate size }\end{array}$} & \multicolumn{4}{|c|}{ Linear regression statistics $†$} \\
\hline & $\boldsymbol{a}$ & $b$ & $r^{2}$ & $\mathbf{P}$ \\
\hline $\mathrm{mm}$ & $\mathrm{Kg} \mathrm{ha}^{-\mathrm{I}}$ & $\mathrm{Kg} \mathrm{ha}^{-1} \mathrm{yr}^{-1}$ & & \\
\hline \multicolumn{5}{|l|}{$\mathrm{C} 4$} \\
\hline $2 \ddagger$ & I 7,976 & $-1,104$ & 0.377 & 0.001 \\
\hline I & 7,880 & 823 & 0.635 & $<0.001$ \\
\hline 0.5 & $5,7 \mid 4$ & 376 & 0.447 & $<0.001$ \\
\hline $0.25 \S$ & 2224 & 139 & 0.289 & 0.007 \\
\hline 0.125 & 1315 & 34 & 0.042 & 0.337 \\
\hline$<0.125$ & 2587 & -200 & 0.296 & 0.006 \\
\hline \multicolumn{5}{|l|}{ C3 } \\
\hline 2 & 7,961 & -434 & 0.216 & 0.022 \\
\hline $\mathbf{I}$ & 2,998 & 328 & 0.645 & $<0.001$ \\
\hline 0.5 & 2,218 & 146 & 0.484 & $<0.001$ \\
\hline 0.25 & 993 & 41 & 0.173 & 0.044 \\
\hline 0.125 & 795 & -20 & 0.058 & 0.256 \\
\hline$<0.125$ & 1,195 & $-7 I$ & 0.293 & 0.006 \\
\hline
\end{tabular}

$\dagger a$ and $b$ represent the intercept and regression coefficient, respectively. $\ddagger$ Bolded rows highlight significant regression effects. $\S$ Italicized rows of data indicate that the values observed reached borderline significance.

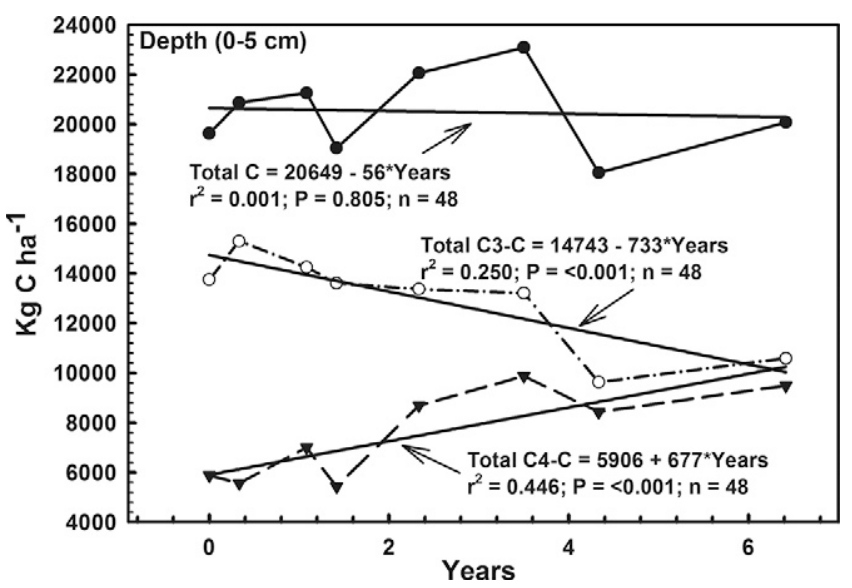

Fig. 2. The total weight ( $\left.\mathrm{kg} \mathrm{ha}^{-1}\right)$ of organic C, C3-C, and C4-C within the 0 - to $5 \mathrm{~cm}$ depth as a function of sampling time.

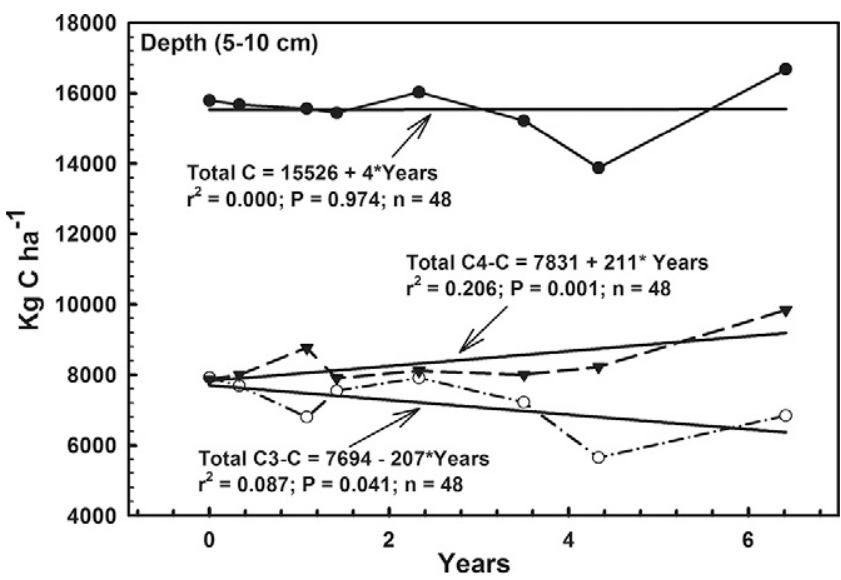

Fig. 3. The total weight (kg ha-1) of organic C, C3-C, and C4-C within the 5 - to $10-\mathrm{cm}$ depth as a function of sampling time. 


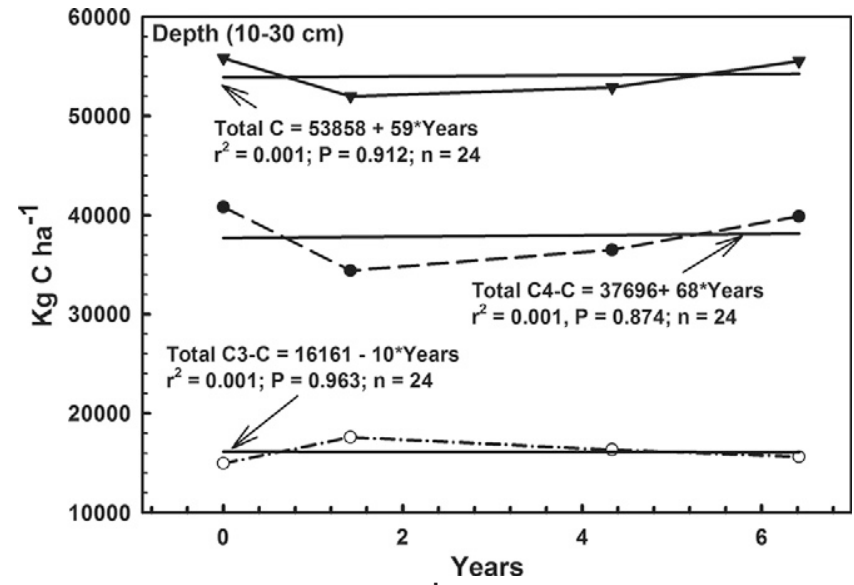

Fig. 4. The total weight $\left(\mathrm{kg} \mathrm{ha}^{-1}\right)$ of organic $\mathrm{C}, \mathrm{C3}-\mathrm{C}$, and C4-C within the $10-$ to $30-\mathrm{cm}$ depth as a function of sampling time.

bromegrass planted on it for 13 yr before beginning the study. The rates of loss or gain of total SOC, C3-C, and C4-C in the 0 - to 5-, 5- to 10-, and 10- to 30-cm depths, respectively, are shown by the slopes and significance of the regression lines in Fig. 2, 3, and 4. The total SOC present at the beginning of this study in May of 1999 was 19,600, 15,800, and 55,800 $\mathrm{kg} \mathrm{ha}^{-1}$ in the 0 - to 5-, 5- to 10-, and 10- to 30-cm depths, respectively. In October 2005, after $6.42 \mathrm{yr}$, these corresponding amounts were $20,100,16,700$, and $55,500 \mathrm{~kg} \mathrm{SOC} \mathrm{ha}^{-1}$. Total soil carbon did not change significantly at any depth (Fig. 2, 3, and 4). However, there was a considerable exchange in amount of C3 derived SOC and C4-derived plant carbon that was introduced into the SOC pool during the experiment (Fig. 2, 3, and 4). In the 0 - to 5-cm depth, both total C3-C and total C4-C changed significantly, with C3-C decreasing from 13,750 to 10,600 $\mathrm{kg} \mathrm{ha}^{-1}$, while the C4-C increased from 5,900 to $9,500 \mathrm{~kg}$ $\mathrm{ha}^{-1}$ (Fig. 2). There were year-to-year fluctuations likely due to drought effects. The decrease of C3-C (from 7,900 to $6,800 \mathrm{~kg}$ $\mathrm{ha}^{-1}$ ) during $6.42 \mathrm{yr}$, in the 5 - to 10 -cm depth (Fig. 3) was not significant. The increase of C4-C from 7,900 to $9,800 \mathrm{~kg} \mathrm{ha}^{-1}$ was significant. Within the 10 - to $30-\mathrm{cm}$ depth (Fig. 4), the changes in total SOC, C3-C, and C4-C were not significant across any of the times sampled.

\section{Rates of Soil Organic Carbon Sequestration or Loss within Soil Aggregate Sizes}

The loss or gain of C3- and C4-SOC by aggregate size at each soil depth over time was determined by using regression analysis to determine which soil aggregate fractions lost SOC and which gained SOC when the grass sod was converted to growing continuous no-till corn. Within the 0 - to $5-\mathrm{cm}$ depth, the largest losses of C3-C (present before planting the no-till corn) was from the 2 -mm aggregate size fraction $(-793$ $\left.\mathrm{kg} \mathrm{C} 3-\mathrm{C} \mathrm{ha}^{-1} \mathrm{yr}^{-1}\right)$. Changes in C3-C amounts per hectare attributable to the other particle sizes were not significant. In contrast, the major gains of C4-C from corn were in the $<2$-mm aggregate size fractions. These gains can be attributed to $\mathrm{C} 4-\mathrm{C}$ from the corn crop and amounted to a combined net gain of $676 \mathrm{~kg} \mathrm{C}^{-}-\mathrm{C} \mathrm{ha}^{-1} \mathrm{yr}^{-1}$ across all fractions (Table 2).

In the 5-to $10-\mathrm{cm}$ depth, the 2-mm size fraction lost $\mathrm{C} 3-\mathrm{C}$ (-280 kg C3-C ha $\left.{ }^{-1} \mathrm{yr}^{-1}\right)$, while the $1 \mathrm{~mm}$ size fraction gained C3-C (+106 kg C3-C ha $\left.{ }^{-1} \mathrm{yr}^{-1}\right)$, likely by inheriting C3-C from the $2-\mathrm{mm}$ size fraction. Results were similar with the 2-mm fraction having less C4-C than the $1,0.5$, and $0.25-\mathrm{mm}$ fractions. Similar changes occurred in the 10 - to $30-\mathrm{cm}$ soil depth (Table 4). The total amount of C3-C or C4-C ha ${ }^{-1}$ in the $2-\mathrm{mm}$ particle sizes decreased, while the amounts in the 1 - and $0.5-\mathrm{mm}$ particles size increased. The total change in the amount of C3-C and C4-C ha ${ }^{-1}$ was not statistically significant for this soil depth (Fig. 4, Table 4).

\section{DISCUSSION}

Through use of an experimental C3 $\leftrightarrow$ C4 plant switch (from bromegrass sod to no-till corn) and periodic collection of soil samples to three depths, soil aggregate size separation, and use of stable $\mathrm{C}$ isotope analyses, we could distinguish changes that occurred for $\mathrm{C}$ originally present from $\mathrm{C} 3$ plants versus that originating from $\mathrm{C} 4-\mathrm{C}$ plants (corn) and changes in amounts of $\mathrm{C} 3-\mathrm{C}$ and $\mathrm{C} 4-\mathrm{C}$ associated with individual soil aggregate size fractions in addition to changes in total SOC.

The very dry conditions that occurred during this study probably contributed to observed changes in amounts of C3-C, C4-C, and SOC, both during the drought and during drought recovery. The complexity of the mechanisms involved with the observed changes are beyond this study and indicate that more definitive, drought-controlled experiments are needed to address the potentially numerous associated questions.

There was no net loss of SOC when smooth bromegrass was converted to no-till corn for a 6 -yr period. These results strongly support the use of no-till technology when grasslands are converted into corn production systems. The grassland type used in this study was a C3-grassland, but it is likely that the same processes will likely occur when C4-grasslands are converted to no-till corn. The results are applicable only to notill continuous corn. Addition research is needed on grassland conversions when no-till cropping systems that include crops such as soybeans are utilized.

There were significant shifts in C3-C and C4-C and their distribution in soil particle size classes in each of the three soil layers that were studied. The largest changes in the amounts of C3-C and C4-C occurred in the 0 - to 5- and 5- to $10-\mathrm{cm}$ soil layers. The $\mathrm{C} 4-\mathrm{C}$ addition within both the 0 - to 5 - and 5- to $10-\mathrm{cm}$ depths likely indicates the additions originated from corn roots and exudates with some of the C4-C also likely coming from decomposing aboveground residues. As expected, the amount of $\mathrm{C} 4-\mathrm{C}$ increased in these soil layers.

The main changes in $\mathrm{C} 3-\mathrm{C}$ and $\mathrm{C} 4-\mathrm{C}$ in soil aggregates was due to a decrease in the amount of soil $\mathrm{C}$ in the larger particle sizes $(2 \mathrm{~mm})$ and an increase in the amount in the smaller particle sizes in the 0 - to 5 - and 5-to 10 -cm soil depths, likely due to the breakdown of the $2-\mathrm{mm}$ size aggregates into smaller size aggregates during the 6 yr no-till farming period. Gains in C4-C also occurred in the smaller $(<1 \mathrm{~mm})$ size fractions, especially within the 0 - to 5 -cm depth. Losses of $\mathrm{C} 4-\mathrm{C}$ in the 2-mm aggregate size fraction at $10-$ to $30-\mathrm{cm}$ depth nearly equaled $\mathrm{C} 4-\mathrm{C}$ gains in the smaller aggregate size fractions. The $\mathrm{C} 4-\mathrm{C}$ originating from the corn would be greatly diluted by the large pool of C4-C already present at this depth. No-till is generally considered as an important practice to minimize SOC loss or enhance SOC sequestration for cropland agriculture and the importance of crop residue return is often mentioned. 
Results from this $6.42 \mathrm{yr}$-long no-till study indicate that an average (1999-2005) of 3140 (range $=0-5560) \mathrm{kg}$ aboveground corn stover $\mathrm{C} \mathrm{ha}^{-1} \mathrm{yr}^{-1}$ was available to return to the soil surface. This average amount is higher than the $2100 \pm$ $100 \mathrm{~kg}$ of MSC ha- $\mathrm{yr}^{-1}(n=3)$ from studies by Allmaras et al. (2004), Clapp et al. (2000), and Kucharik et al. (2001) for no-till continuous corn as identified by Johnson et al. (2006). However, as shown in Table 1, amounts available in 2002 and 2003 were low or lower than the 2,100 $\mathrm{kg}$ of MSC ha $\mathrm{yr}^{-1}$, and in 2004 (a nearly average climate year in Fig. 1) there was likely only limited residue carryover from previous years. Even though a wide range of aboveground corn stover $\mathrm{C}$ was measured in this study, our data provides support but not refinement to MSC information reported by Johnson et al. (2006).

\section{CONCLUSIONS}

In the near future, there may be a massive conversion of grasslands in the CRP to grain crops, particularly corn, because of the demand for grain crops for biofuels. The use of no-till conversion of smooth bromegrass to corn production, followed by continuous no-till corn production did not result in any net change in SOC during a 6 -yr production period in the western Cornbelt, USA. There was a significant change in the relative amount of SOC that was from the $\mathrm{C} 3$ bromegrass and the $\mathrm{C} 4$ corn during the $6 \mathrm{yr}$, and a redistribution of SOC into different particle size classes with the increase in smaller particle size classes. If CRP grasslands are converted to grain crop production, the data from this study strongly support the use of no-till farming practices as a method of conserving the SOC that was sequestered during the time period that the land was in the CRP. This study illustrates the power of utilizing measurements of $\delta^{13} \mathrm{C}$ and a C3 $\leftrightarrow$ C 4 plant switch to identify the source, amount, and depth of newly sequestered SOC.

\section{ACKNOWLEDGMENTS}

The authors gratefully acknowledge the important contributions of Mr. Edward Buenger and Ms. Elizabeth Pruessner, and Jedd Carrol, Genevieve Holzapfel, and other student employees in the Soil-PlantNutrient Research Unit of USDA/ARS, the important assistance provided by the National Soil Survey Laboratory of USDA/NRCS, and field assistance and coordination with NRCS by Mr. Steve Scheinost, Asst. State Soil Scientist for USDA/NRCS in Nebraska. This study is supported by USDA-ARS funding and addresses objectives of the GRACEnet and the REAP Cross Location Research projects.

\section{REFERENCES}

Allmaras, R.R., D.R. Linden, and C.E. Clapp. 2004. Corn-residue transformations into root and soil carbon as related to nitrogen, tillage, and residue management. Soil Sci. Soc. Am. J. 68:1366-1375.

Angers, D.A., N. Bissonnette, A. Legere, and N. Samson. 1993a. Microbial and biochemical changes induced by rotation and tillage in a soil under barley production. Can. J. Soil Sci. 73:39-50.

Angers, D.A., N. Samson, and A. Legere. 1993b. Early changes in water-stable aggregation induced by rotation and tillage in a soil under barley production. Can. J. Soil Sci. 73:51-59.

Balesdent, J., and A. Marriotti. 1996. Measurement of soil organic matter turnover using 13C natural abundance. p. 83-112. In T.W. Boutton and S. Yamasaki (ed.) Mass spectrometry of soils. Marcel Dekker, New York.

Balesdent, J., G.H. Wagner, and A. Marriotti. 1988. Soil organic matter turnover in long-term field experiments as revealed by carbon-13 natural abundance. Soil Sci. Soc. Am. J. 52:118-124.
Boutton, T.W. 1991. Stable carbon isotope ratios of natural materials: I. Sample preparation and Mass spectrometric analysis. p. 155-171. In D.C. Coleman and B. Fry (ed.) Carbon isotope techniques. Academic Press, New York.

Boutton, T.W. 1996. Stable carbon isotope ratios of soil organic matter and their use as indicators of vegetation and climate change. p. 47-82. In T.W. Boutton and S.Yamasaki (ed.) Mass spectrometry of soils. Marcel Dekker, New York.

Burt, R. (ed.) 2004. Soil Survey Laboratory Methods Manual. Soil Survey Investigations Rep. No. 42, Version 4.0. NRCS, Washington, DC.

Cassman, K.G. 1999. Ecological intensification of cereal production systems. Yield potential, soil quality, and precision agriculture. Proc. Natl. Acad. Sci. USA 96:5952-5959.

Cassman, K., V. Eidman, and E. Simpson. 2006. Convergence of agriculture and energy: Implications for research and policy. CAST Commentary QTA2006-3. Council for Agricultural Science and Technology, Ames, IA

Chaney, K., and R.S. Swift. 1984. The influence of organic matter on aggregate stability in some British soils. J. Soil Sci. 35:223-230.

Clapp, C.E., R.R. Allmaras, M.F. Layese, D.R. Linden DR, and R.H. Dowdy. 2000. Soil organic carbon and C-13 abundance as related to tillage, crop residue, and nitrogen fertilization under continuous corn management in Minnesota. Soil Tillage Res. 55:127-142.

Clay, D.E., C.G. Carlson, S.A. Clay, C. Reese, Z. Liu, J. Chang, and M.M. Ellsbury. 2006. Theoretical derivation of stable and nonisotopic approaches for assessing soil organic carbon turnover. Agron. J. 98:443-450.

Deines, P. 1980. The isotopic composition of reduced organic carbon. p. 329406. In P. Fritz and J.C. Fontes (ed.) Handbook of environmental isotope geochemistry. Vol. 1. The Terrestrial Environment. Part A. Elsevier, Amsterdam.

Follett, R.F., J. Kimble, S.W. Leavitt, and E. Pruessner. 2004. Potential use of C isotope analyses to evaluate paleoclimate. Soil Sci. 169:471-488.

Follett, R.F., E.A. Paul, S.W. Leavitt, A.D. Halvorson, D. Lyon, and G.A. Peterson. 1997. Carbon isotope ratios of Great Plains soils in wheat-fallow systems. Soil Sci. Soc. Am. J. 61:1068-1077.

Farm Service Agency. 2007. Summary of practice acreages for active contracts by program year. Available at http://content.fsa.usda.gov/crpstorpt/ rlpracyr/rlpracyr2.htm [accessed 14 Jan. 2008; verified 31 Dec. 2008]. FSA, USDA, Conservation and Environmental Programs Division, Washington, DC.

Foster, R.C. 1988. Microenvironments of soil microorganisms. Biol. Fertil. Soils 6:189-203

Graham, R.L., R. Nelson, J. Sheehan, R.D. Perlack, and L.L. Wright. 2007. Current and potential US corn stover supplies. Agron. J. 99:1-11.

Haynes, R.J., and R.S. Swift. 1990. Stability of soil aggregates in relation to organic constituents and soil water content. J. Soil Sci. 41:73-83.

Johnson, J.M.-F., R.R. Allmaras, and D.C. Reicosky. 2006. Estimating source carbon from crop residues, roots, and rhizodeposition using the National Grain-Yield Database. Agron. J. 98:622-636.

Kay, B.D. 1997. Soil structure and organic carbon: A review. p. 169-197. In R. Lal et al. (ed.) Soil processes and the carbon cycle. CRC Press, Boca Raton, FL.

Keeling, C.D., S.C. Piper, R.B. Bacastow, M. Wahlen, T.P. Whorf, M. Heimann, and H.A. Meijer. 2001. Exchanges of atmospheric CO2 and $13 \mathrm{CO} 2$ with the terrestrial biosphere and oceans from 1978 to 2000. I. Global aspects. SIO Reference No. 01-06 (revised). Scripps Institute of Oceanography, La Jolla, CA.

Kemper, W.D., and R.C. Rosenau. 1986. Aggregate stability and size distribution. p. 425-442. In Methods of soil analyis, Part 1. Physical and mineralogical methods. Agron. Monogr. No. 9. 2nd ed. ASA and SSSA, Madison, WI.

Kucharik, C.J., K.R. Brye, J.M. Norman, J.A. Foley, S.T. Gower, and L.G. Bundy. 2001. Measurements and modeling of carbon and nitrogen cycling in agroecosystems of southern Wisconsin: Potential for SOC sequestration during the next 50 years. Ecosystems 4:237-258.

Lal, R., R.F. Follett, B.A. Stewart, and J.M. Kimble. 2007. Soil carbon sequestration to mitigate climate change and advance food security. Soil Sci. 172:943-956.

Liebig, M., L. Carpenter Boggs, J.M.F. Johnson, S. Wright, and N.W. Barbour. 2006. Cropping system effects on soil biological characteristic in the Great Plains. Renew. Agric. Food Syst. 21:36-48. 
Perlack, R.L., L.L. Wright, A.F. Turhollow, R.L. Graham, B.B. Stokes, and D.C. Erbach. 2005. Biomass as feedstock for a Bioenergy and bioproducts industry: The technical feasibility of a billion-ton annual supply. DOE/ GO-102005 and ORNL/TM-2005/66. Available at http://feedstockreview.ornl.gov/pdf/billion_ton_vision.pdf [accessed 14 Jan. 2008; verified 31 Dec. 2008]. National Technical Information Service, Springfield, VA.

Robertson, G.P., V.H. Dale, O.C. Doering, S.P. Hamburg, J.M. Melillo, M.M. Wander, W.J. Parton, R. Pouyat, P.R. Adler, J. Barney, R.M. Cruse, C.S. Duke, P.M. Fearnside, R.F. Follett, H.K. Gibbs, J. Goldemberg, D. Mladenoff, D. Ojima, M.W. Palmer, A. Sharpley, L. Wallace, K.C. Weathers, J.A. Wiens, and W.W. Wilhelm. 2008. Sustainable biofuels redux. Science 322:49-50.

Simpson, R.T., S.D. Frey, J. Six, and R.K. Thiet. 2004. Preferential accumulation of microbial carbon in aggregate structures of no-tillage soils. Soil Sci. Soc. Am. J. 68:1249-1255.
Six, J., S.D. Frey, R.K. Thiet, and K.M. Batten. 2006. Bacterial and fungal contributions to carbon sequestration in agroecosystems. Soil Sci. Soc. Am. J. 70:555-569.

Tilman, D., K.G. Cassman, P.A. Matson, R. Naylor, and S. Polasky. 2002. Agricultural sustainability and intensive production practices. Nature 418:671-677.

Wilts, R., D.C. Reicosky, R.R. Allmaras, and C.E. Clapp. 2004. Long-term corn residue effects: Harvest alternatives, soil carbon turnover, and rootderived carbon. Soil Sci. Soc. Am. J. 68:1342-1351.

Wright, S.F., and A. Upadhyaya. 1998. A survey of soils for aggregate stability and glomalin, a glycoprotein produced by hyphae of arbuscular mycorrhizal fungi. Plant Soil 198:97-107.

Yoder, R.E. 1936. A direct method of aggregate analysis of soils and a study of the physical nature of erosion losses. J. Am. Soc. Agron. 28:337-351. 